\title{
PENGARUH SOSIAL TERHADAP PEMBERIAN ASI
}

\author{
Wahyu Ramadhan Nur Zainal
}

Universitas Islam Negeri Alauddin Makassar

E-mail : wnurzainal@gmail.com

\section{PENDAHULUAN}

ASI (Air Susu Ibu) adalah makanan paling utama dan sempurna bagi bayi. ASI mengandung hampir semua zat gizi yang diperlukan oleh bayi agar tumbuh dan berkembang secara optimal.

Ada beberapa faktor yang mempengaruhi praktek menyusui yang efektif yaitu ; sosial demografi ibu dan keluarga, struktur dan dukungan sosial (peran suami dan keluarga), status kesehatan ibu dan bayi, pengetahuan, sikap dan keterampilan ibu, kebiasaan makan, pelayanan kesehatan, organisasi dan kebijakan, kultural, ekonomi, dan lingkungan.

Menurut Simanjuntak bahwa penyebab kegagalan praktek ASI eksklusif bermacam macam, seperti pemberian makanan prelakteal, ibu harus bekerja, bayi sakit, faktor kelelahan atau kurang percaya diri dari ibunya, dan lain sebagainya. Penelitian ASUH tahun 2002 menunjukkan bahwa bukan semata-mata faktor pengetahuan ibu yang mempengaruhi keberhasilan ASI ekslusif, tetapi juga berbagai faktor sosial budaya di masyarakat yang mempengaruhi keberhasilan ASI eksklusif.

Inisiasi Menyusui Dini (IMD) merupakan upaya agar hak bayi yang selama ini terenggut oleh para praktisi kelahiran yang pada saat membantu proses persalinan dapat terkembalikan. Dalam kondisi yang seperti ini, ketahanan tubuh bayi dapat mengalami penurunan hingga 25 persen dan bahkan dapat terjadi goncangan psikologis pada bayi sebagai akibat dari kehilangan perlindungan dari ibunya yang dapat mempengaruhi kualitas perkembangan fisik, psikologis, dan kecerdasan anak dikemudian hari. Pemahaman dan pelaksanaan yang baik tentang IMD adalah dasar utama dan kuat dalam proses tumbuh kembang anak dan pemenuhan Air Susu Ibu sejak bayi lahir sampai usia 6 bulan akan meningkatkan poin kecerdasan intelektual yang lebih tinggi sebesar 12,9 pada usia 9 tahun.

Tidak hanya menyukseskan pemberian ASI eksklusif semata tetapi Inisiasi Menyusui Dini juga memperlihatkan hasil nyata dalam menyelamatkan nyawa bayi. Apabila semua bayi diberi kesempatan menyusui sendiri setelah lahir dengan membiarkan kontak kulit antara ibu ke kulit bayi minimal selama satu tahun maka satu juta nyawa bayi dapat diselamatkan. 
Keuntungan menyusui meningkat seiiring lama menyusui hingga 6 bulan. Setelah itu, dengan tambahan makanan pendamping ASI di usia 6 bulan. Pemberian ASI dalam jangka 2 tahun atau lebih, akan meningkatkan keuntungan dalam kegiatan menyusui. ASI mempunyai banyak manfaat untuk bayi sepert; sebagai nutrisi untuk bayi, meningkatkan daya tahan tubuh bayi, meningkatkan kecerdasan, meningkatkan jalinan kasih sayang, menyebabkan pertumbuhan yang baik, dan mengurangi kejadian karies dentis.

\section{PEMBERIAN ASI (Air Susu Ibu)}

Pada Tahun 2010 pencapaian pemberian air susu ibu (ASI) di Indonesia masih rendah. Pada bayi usia enam bulan, pemberian ASI di Indonesia hanya 15,3 persen, dan pada tahun 2013 pemberian ASI eksklusif hanya sebesar 30,2 persen, sementara target nasional di atas 80 persen. Kejadian adalah ancaman bagi tumbuh kembang anak. Bayi yang tidak diberi ASI dari lahir sampai usia 6 bulan dapat berakibat buruk pada gizi dan kesehatan bayi (Badan Penelitian dan Pengembangan Kesehatan,2013).

Menurut Fikawati (2010), yang menjadi penyebab kegagalan praktek ASI eksklusif bermacam-macam, antara lain budaya memberikan makanan pralaktal, memberikan tambahan susu formula karena ASI tidak keluar, menghentikan pemberian ASI karena bayi atau ibu sakit, ibu harus bekerja, serta ibu ingin mencoba susu formula. Faktor predisposisi kegagalan ASI eksklusif antara lain adalah karena ibu tidak difasilitasi melakukan inisiasi menyusui dini (IMD). Selain itu, gencarnya promosi susu formula dan kebiasaan memberikan makanan/minuman secara dini pada sebagian masyarakat, menjadi pemicu kurang berhasilnya pemberian ASI eksklusif.

Di negara berkembang, praktik menyusui telah berhasil menyelamatkan sekitar 1,5 juta bayi pertahun. Atas dasar tersebut World Health Organization (WHO) merekomendasikan untuk hanya memberikan ASI sampai bayi berusia 4-6 bulan. Menurut pendapat Steven Allen dalam siaran pers UNICEF, 2004 disitasi oleh Roesli (2000), ASI bukanlah sekedar makanan tetapi penyelamat kehidupan. Setiap tahunnya lebih dari 25.000 bayi Indonesia dan 1,3 juta bayi di seluruh dunia dapat diselamatkan dengan pemberian ASI eksklusif pada tahun 1999.

\section{PENGARUH KELUARGA TERHADAP PEMBERIAN ASI}

Kemampuan untuk dapat bertahan terus untuk menyusui juga dipengaruhi oleh dukungan yang didapatkan. Dalam hal ini dukungan suami maupun keluarga sangat besar pengaruhnya. Suami dapat menguatkan motivasi ibu agar menjaga komitmen dengan ASI dan 
tidak mudah tergoda dengan susu formula atau makanan lainnya. Suami juga harus membantu secara teknis seperti mengantar kontrol ke dokter atau bidan dan menyediakan makanan bergizi. Seorang ibu yang kurang mendapat dukungan dari keluarga dan suami akan lebih mudah dipengaruhi untuk beralih ke susu formula.

Joshi et al. menyebutkan bahwa rendahnya angka prevalensi ASI eksklusif yang didapat dari penelitian mereka salah satunya karena kurangnya dukungan yang diberikan oleh keluarga ibu.

Peran ayah pada praktik pemberian ASI dapat dipengaruhi oleh pengetahuan dan sikap ayah terhadap hal-hal yang berhubungan dengan pemberian ASI, faktor sosial ekonomi, serta terpapar dengan berbagai sarana komunikasi media massa dan interpersonal. Memberikan dukungan emosional pada ibu saat proses persalinan, ikut serta dalam proses pengambilan keputusan tentang pemberian makan bayi, terlibat dalam urusan perawatan anak, dalam pekerjaan rumah tangga, dalam ekonomi keluarga, serta berperan dalam menjaga keharmonisan hubungan rumah tangga merupakan peran yang sangat penting bagi seorang ayah.

Hasil penelitian pemantauan kesehatan dan gizi Provinsi Sumatera Barat pada tahun 2004 menunjukkan bahwa balita yang mendapat ASI eksklusif sampai berumur 4 bulan hanya sebesar 19,4\%, dalam kehidupan masyarakat Minangkabau, keluarga luas matrilineal masih mempunyai hubungan yang cukup kuat. Seorang ibu tidak akan mudah menetapkan aturan sendiri karena di sekelilingnya ada nenek, ibu, kakak, dan adik perempuan yang turut berperan dalam pengasuhan anak.

\section{FAKTOR PENDIDIKAN DALAM PEMBERIAN ASI}

Ilyas (2002) berpendapat bahwa pendidikan sangat besar pengaruhnya terhadap perilaku. Seseorang yang berpendidikan tinggi perilakunya akan berbeda dengan seseorang yang berpendidikan rendah.

Namun dalam pemberian ASI, walaupun ibu berpendidikan tinggi tidak membuat ibu untuk merubah perilaku memberikan ASI eksklusif pada bayinya. Tingkat pendidikan masyarakat yang rendah seringkali menjadi tuduhan utama sebagai penyebab sehingga ibu-ibu tidak mempunyai kesempatan untuk mendapatkan informasi yang baik. Namun dengan majunya sistem informasi komunikasi saat ini, nampaknya tingkat pendidikan masyarakat rendah tidak lagi menjadi faktor utama yang menyebabkan penggunaan ASI masih rendah. 
Tidak terdapat hubungan yang signifikan antara pengetahuan ibu, tingkat pendidikan ibu dan tingkat pendidikan suami dan pemberian ASI eksklusif. Penelitian yang dilakukan oleh Sartono mengemukakan bahwa pengetahuan ibu dan pendidikan ibu tidak berhubungan dengan pemberian ASI eksklusif karena mereka berhasil menyusui secara eksklusif lebih karena mengikuti anjuran menyusui dari penolong persalinan yang menumbuhkan niat pribadi untuk menyusui bayinya. Selain itu didukung oleh kondisi dimana pada saat setelah persalinan ASI segera keluar sehingga segera bisa diberikan kepada bayi dan bayi tidak sempat diberikan susu formula atau dengan kata lain berhasil tidaknya menyusui eksklusif berhubungan dengan pelaksanaan manajemen laktasi yang dilaksanakan oleh petugas penolong persalinan.

\section{PENGARUH PEMBERIAN SUSU FORMULA PADA BAYI}

Hesti Kristina P. Tobing, Wakil Ketua Ikatan konselor Menyusui Indonesia (IKMI), mengemukakan, para ibu menyusui perlu mengetahui abahwa tidak ada satu pun susu formula yang bebas dari kuman. WHO dan FDA juga mengemukakan bahwa semua susu formula tidak steril dan berisiko terkena bakteri termasuk sakazaki.

Dalam sebuah artikel Ikatan Dokter Anak Indonesia (IDAI), hingga 80 persen susu formula mengandung protein casein yang pada akhirnya dibuang oleh bayi karena sulit dicerna. Protein casein tersebut dibuang melalui ginjal, sehingga ginjal bayi akan dipaksa untuk membuang casein. Hubertin menyatakan bahwa, Protein casein merupakan salah satu pemicu banyakji kasus gagal ginjal yang terjadi pada anak.

Selain sebagai nutrisi, lemak yang ada dalam ASI juga dapat membentu enzim penghancur lemak yang tidak dibutuhkan oleh tubuh. Enzim penghancur lemak ini tidak terdapat pada susu formula sehingga lemak berdiam didalam tubuh dan dapat mengakibatkan pengapuran pada pembuluh darah.

Bagi ibu yang tidak bisa memberikan ASI pada bayinya karena permasalahan pada ASI maka jalan satu-satunya adalah memberikan susu formula sebagi pengganti ASI untuk memberikan nutrisi. Namun, kandungan nutrisi yang terkandung dalam susu formula tidak dapat menyamai kandungan nutrisi yang terdapat pada ASI. Termasuk AA dan DHA (Komponen utama asam lemak yang mempunyai peran penting dalam perkembangan korteks otak dan retina). 


\section{DAFTAR PUSTAKA}

Syahrir, S., \& Alam, S. (2016). Faktor-Faktor yang Berhubungan Dengan Teknik Menyusui pada Ibu di Puskesmas Pattallassang Kabupaten Takalar. Al-Sihah: The Public Health Science Journal, 8(2).

Alam, S., \& Syahrir, S. (2017). Hubungan Personal Hygiene Pemberian Susu Formula Dengan Kejadian Diare Pada Bayi di Kelurahan Dannuang Kecamatan Ujung Loe Kabupaten Bulukumba Tahun 2016. HIGIENE: Jurnal Kesehatan Lingkungan, 3(2), 76-86.

Alam, S., \& Karini, T. A. (2020). Islamic Parenting" Pola Asuh Anak: Tinjauan Perspektif Gizi Masyarakat".

Fajar, N. A., Purnama, D. H., Destriatania, S., \& Ningsih, N. (2018). Hubungan Pemberian ASI Eksklusif dalam Prespektif Sosial Budaya di Kota Palembang. Jurnal Ilmu Kesehatan Masyarakat, 9(3), 226-234.

Evareny, L., Hakimi, M., \& Padmawati, R. S. (2010). Peran ayah dalam praktik menyusui. Berita Kedokteran Masyarakat, 26(4), 187-195.

Widiyanto, S. (2012). Hubungan pendidikan dan pengetahuan ibu tentang ASI eksklusif dengan sikap terhadap pemberian ASI eksklusif (Doctoral dissertation, UNIMUS).

Zaenab, S., Alasiry, E., \& Idris, I. (2016). Pengaruh pemberian ASI eksklusif terhadap pertumbuhan bayi di wilayah kerja puskesmas poasia kota Kendari. Jst Kesehatan, 6(1), 97-102.

Yulianti, F. (2014). Hubungan Antara Karakteristik, Tingkat Pengetahuan Dan Dukungan Keluarga Terhadap Pemberian Asi Eksklusif Di Wilayah Kerja Puskesmas Siantan Hulu Kecamatan Pontianak Utara Tahun 2014. Jurnal Mahasiswa PSPD FK Universitas Tanjungpura, 1(1).

Maslahah, N. (2010). Perbedaan Pengaruh Pemberian ASI dengan Pemberian Susu Formula terhadap tingkat IQ Anak. 